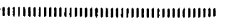

\title{
技術報告
}

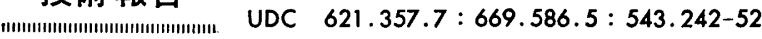

\section{電気亜鉛めつき工程めつき浴および各種処理浴の 自動濃度分析システムの開発*}

\author{
松本龍太郎** . 佐藤 公隆 ${ }^{* * *}$. 鈴木 堅市**
}

\author{
Development of On-Line Analysis System for Components in \\ Plating Bath and Some Chemical Treatment Baths of Electric \\ Galvanizing Process
}

\author{
Ryutaro Matsumoto, Kimitaka SAto, and Ken-ichi SuzukI
}

\section{Synopsis :}

The fundamental approaches for an automatic concentration control system were made of five kinds of chemical treatment baths in an electric galvanizing process. The results obtained are summarized as follows: (1) The concentration of $\mathrm{NaOH}$ or $\mathrm{Na}_{4} \mathrm{SiO}_{4}$ in an alkali-using cleaning bath and $\mathrm{H}_{2} \mathrm{SO}_{4}$ in a pickling bath can be analized with electric conductivity cell. (2) The concentration of $\mathrm{ZnSO}_{4} \cdot 7 \mathrm{H}_{2} \mathrm{O}$ and $\mathrm{H}_{2} \mathrm{SO}_{4}$ in an electric galvanizing bath can be automatically analyzed with the combination of specific gravity meter and $\mathrm{pH}$ meter. (3) The concentration of $\left(\mathrm{NH}_{4}\right)_{2} \mathrm{CO}_{3}$ in an electolytic cleaning bath can be automatically analyzed with electric conductivity cell and those of $\mathrm{CrO}_{3}$ and its addition in an electrolytic chromate bath can be done with the combination of electric conductivity cell and specific gravity meter.

\section{1. 緒言}

鉄鋼の製造工程における自動化, 省力化の推進はめざ ましく, 各種自動化装置, コンピュータの導入, 検出端 の開発などに鋭意努力がはらわれてきた，その中で，工 程管理分析や鉄鋼化学分析1)2) についても積極的に自動 化が図られ, 工程操業の能率向上や体質改善に大きく貢 献している。

その一環として, 現場生産部門の要請の強いめつき工 程における各種処理浴管理分析の自動化を図るための一 連の研究を行い，すでに溶融覀鉛めつき工程における各 種クロメート処理浴中クロム酸濃度の自動分析システム について報告した3). 続いて，電気亜鉛めつき工程にお けるめつき浴およびその前後工程における各種処理浴の 自動分析システムについて検討を行つた.

本稿では, 電気亜鉛めつき工程の 20 数種におよぶ処 理浴のうち, アルカリ, 酸洗, めつき, 電解処理および

\begin{abstract}
クロメートの各処理浴について自動分析システムの検討 を行つた結果を述べる。
\end{abstract}

\section{2. 検出端の選択}

液体あるいは溶液の連続自動分析法としては，単純な 物理定数の測定から, 電気化学的方法, 化学反応を利用 したものなど種々の方法が考えられる.物理的方法は測 定や計器の保守が簡単な場合が多く, 工業的にも広い分 野で活用されている.しかし，これらの方法の多くは選 択性が悪いため，とくに多成分系溶液へ適用する場合に は詳細な検討が必要である.これに比較して, 化学的方 法は一般に選択性がよく，複雑な成分系溶液の分析にお いても高い精度が期待できるものの, 試薬の調製, 計器 の取り扱いなど保守の面がはん雑になり, 生産現場では あまり歓迎されないことが多い.

ここでは, 各処理浴の管理項目と測定精度を考虑しな がら, 計器の取り扱いおよび保守が容易なものとして電

* 昭和 54 年 1 月 16 日受付 (Received Jan. 16, 1979)

** 新日本製鉄 (株)基整研究所 (Fundamental Research Laboratories, Nippon Steel Corp., 1618 Ida Nakahara-ku Kawasaki 211)

*** 新日本製鉄 (株) 基礎研究所理博 (Fundamental Research Laboratories, Nippon Steel Corp.) 
導度計，比重計および $\mathrm{pH}$ 計の適用性を検討することに した。

\section{1 電等度測定}

めつき工程における各種処理浴は一般に高濃度のもの が多く，したがつて電導度も高い。このような溶液の電 導度の測定は電極法よりもむしろ電磁誘導法のほうがす ぐれているので，溶融要鉛めつき工程のクロメート処理 浴3) と同じょうに電磁誘導式を採用した.

単一成分溶液では，一般に電導度と濃度との間に一定 の相関関係があるが，多成分系溶液ではとこに含まれる すべての電解質成分が電導度に影響を与える．したがつ て, 測定したい成分以外の”成分の電導度への影響の程 度, さらにそれらの成分の操業中での濃度変動が重要な 因子となる，また，液体の電導度は温度の影響を大きく 受けるので, 工業用計器では温度係数を正確に求めて温 度補償回路を設ける必要がある。

\section{2 比面測定}

単一成分溶液の濃度管理には，比重を検出する方法が 工業的レベルで多く用いられているい，此重は物理定数 の中でも最も基本的なものの一つであり，そのデータが 豊富かつ正確で測定が比較的簡単であるからである．比 重法は電導度法と同じように，多成分系溶液への適用は 困難である場合も多いが，被測定成分以外の成分の濃度 が一定であるとかその変動が小さいときには適用が可能 になる。

比重は温度および圧力の影響を受けやすい．圧力は液 体の場合ほとんど影響しないので一般に無視することが できるが，温度の影響は比較的大きいため補償する必要 がある.一般には，温度が高くなると比重は隇少し，ま た潾度が高いほど温度俰数は大きい，工業用比重計では 常用温度を中心として $\pm 10 \sim 20^{\circ} \mathrm{C}$ の範囲内で自動的に 温度補償できる機能を備えているものが多い。

工業用比重計は, 測定原理別に科量式, 浮子式, 差生 式および重量式などがある，この中で，工業的に最も 普及しているのは構造的に簡単な差圧式比重計である.

差圧式比重計にはさらに気泡式と隔膜式があるが，ここ ではめつき浴などの化学処理浴の濃度管理に適当と考え られる気泡式差圧比重計について簡単にふれる.

いま，Fig. 1 に示すように，測定液の中に長さの異な つた 2 本の気泡管を㨂入し，较り弁を通して圧縮空気を 送つて気泡管の先端より気泡として放出するようにする と,

気泡管の背圧の差 $=($ 気泡管の長さの差 $)$ $\times$ (液体比量)

となる原理を応用したものである・このままでは部分目

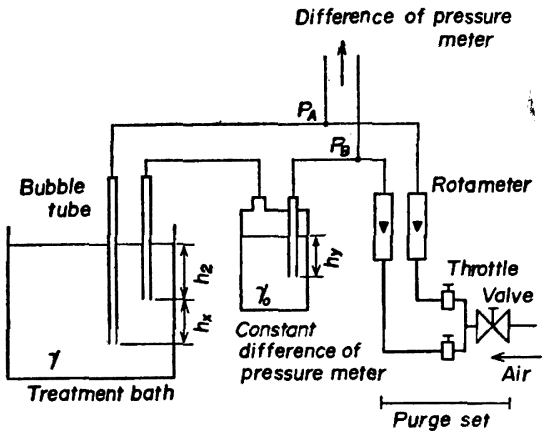

Fig. 1. Specific gravity meter used in industrial process.

盛をとることができず，高精度の検出は困難であるので 一般には定差圧槽（压力加算装置）を併設して基準比重 值からの比重の变化を検出する.すなわち，Fig. 1 にお いて差圧計の受ける圧力は,

$$
P_{\mathrm{A}}-P_{\mathrm{B}}=r\left(h_{2}+h_{x}\right)-\left(r h_{2}+r_{0} h_{y}\right)=r h_{x}-r_{0} h_{y}
$$

で表される， $r_{0} h_{y}$ が定差压槽の圧力であり，気泡管の長 さの差 $h_{x}$ および定差圧槽の圧力 $r_{0} h_{y}$ を適当に選べば, 差圧, $P_{\mathrm{A}}-P_{\mathrm{B}}$ は比重変化範囲 $r_{\max }-r_{\min }$ となる.

\section{3. システム化の検討}

ここでは，電気亜鉛めつき工程におけるめつき浴およ びアルカリ, 酸洗, 電解洗浄, 電解クロメートなどの処 理浴に対して，工業用分析計の適用性およびシステム化 の検討を行つた結果について述べる.

\section{1 アルカリ処理浴}

アルカリスプレーや電解脱脂には, 水酸化ナトリウム やオルトケイ酸ナトリウムがそのまま，あるいは界面活

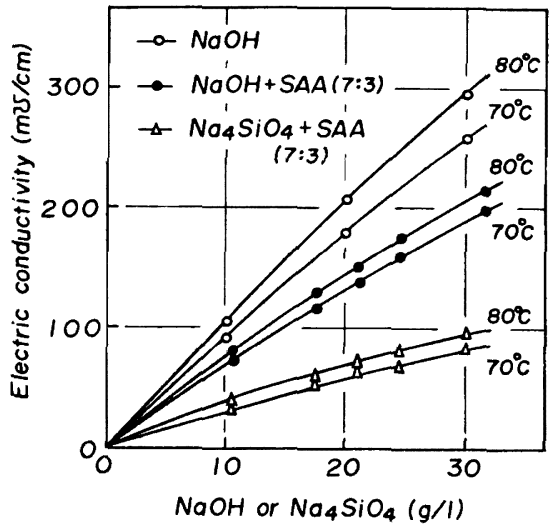

Fig. 2. Gorrelation between concentration of $\mathrm{NaOH}$ or $\mathrm{Na}_{4} \mathrm{SiO}_{4}$ and electric conductivity in an alkali-using cleaning bath. SAA indicates surface active agent. 
Table 1. Correlation between concentration of surface active agent and electric conductivity in an alkali-using cleaning bath $(\mathrm{m} \mho / \mathrm{cm})$.

\begin{tabular}{|c|c|c|c|c|c|c|c|}
\hline \multirow{2}{*}{ Temperature } & \multirow{2}{*}{$\begin{array}{l}\text { Concentration } \\
\text { of alkali }(g / l)\end{array}$} & \multicolumn{3}{|c|}{$\mathrm{NaOH}: \mathrm{SAA}^{*}$} & \multicolumn{3}{|c|}{$\mathrm{Na}_{4} \mathrm{SiO}_{4}: \mathrm{SAA}^{*}$} \\
\hline & & $6: 4$ & $7: 3$ & $8: 2$ & $6: 4$ & $7: 3$ & $8: 2$ \\
\hline $70^{\circ} \mathrm{C}$ & $\begin{array}{l}18 \\
24\end{array}$ & $\begin{array}{l}120 \\
-\end{array}$ & $\begin{array}{l}118 \\
154\end{array}$ & $\overline{155}$ & 63 & $\begin{array}{l}56 \\
71\end{array}$ & $\overrightarrow{67}$ \\
\hline $80^{\circ} \mathrm{C}$ & $\begin{array}{l}18 \\
24\end{array}$ & 113 & $\begin{array}{l}131 \\
169\end{array}$ & $\overline{174}$ & 68 & $\begin{array}{l}62 \\
78\end{array}$ & $\overline{73}$ \\
\hline $90^{\circ} \mathrm{C}$ & $\begin{array}{l}18 \\
24\end{array}$ & 140 & $\begin{array}{l}139 \\
181\end{array}$ & $\overline{180}$ & $\begin{array}{l}73 \\
-\end{array}$ & $\begin{array}{l}66 \\
82\end{array}$ & $\overline{79}$ \\
\hline
\end{tabular}

$\uparrow$ SAA indicates surface active agent

性剤を添加して使用されるそこで，まずアルカリ処理 浴の濃度と電導度，界面活性剂の添加の影響，温度の効 果について調べた. その結果の一部を Fig. 2 に示す. すなわち，水酸化ナトリウム溶液に $7: 3$ の割合で界面 活性戍を添加すると, 電導度は約 $30 \%$ 減少する.オル トケイ酸ナトリウム溶液の電導度は, 水酸化ナトリウム 溶液の場合のほほ半分である.

また，アルカリと界面活性剤の比を $6: 4,7: 3$ およ び $8: 2$ と変えた場合について, 電導度の变化の様子を 調べた結果 Table 1 に示すように水酸化ナトリウム溶 液では電導度にほとんど影響がなく，オルトケイ酸ナト リウム溶液ではいくらかの影響が認められる.

以上の結果から，操業中に界面活性剤の添加比が大き く変動すると誤差の原因となるが，この比が大幅に変ら ない限り，アルカリ処理浴の濃度管理は電導度計によつ て可能である.

\section{2 酸洗処理浴}

アルカリ洗浄した鋼板は電解酸洗処理される．この酸 洗処理浴には硫酸が用いられ，その濃度と温度は目的に 応じて使い分けるためその範囲はかなり広い.さらに， この処理浴中には溶解した鉄が共存しており，その量が 比重や電導度に影響を与えるものと考えられる.ここで は, 硫酸溶液について濃度と電導度との関係におよぼす 温度と 鉄共存量の影響を 調べた. その結果を Fig. 3〜4 に示す. すなわち，溶液中の硫酸濃度が一定であつて も鉄溶存量の増加とともに電導度は減少する.したがつ て, 電導度法によつて処理浴中の硫酸濃度を測定するに は，鉄を一定量溶解した硫酸溶液を基準にすればよく， 鉄溶存量の变動のあまり大きくない範囲内においては硫 酸濃度と電導度との間によい相関が求められる. 例えば $70 \mathrm{~g} / \mathrm{l}, 40^{\circ} \mathrm{C}$ の硫酸溶液で 鉄溶存量が $10 \mathrm{~g} / \mathrm{l}$ から士 $5 \mathrm{~g} / 1$ だけ変化した場合, 電導度では $\pm 10 \mathrm{m \mho} / \mathrm{cm}$ の変 化となり，それは $\pm 1.9 \mathrm{~g} / 1$ の硫酸量に相当する.

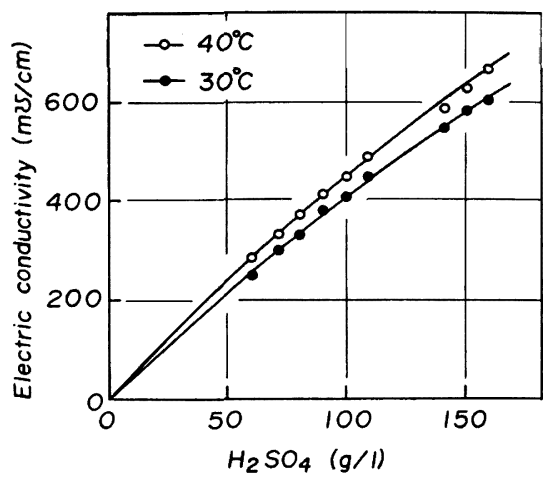

Fig. 3. Correlation between concentration of $\mathrm{H}_{2} \mathrm{SO}_{4}$ and electric conductivity in a pickling bath.

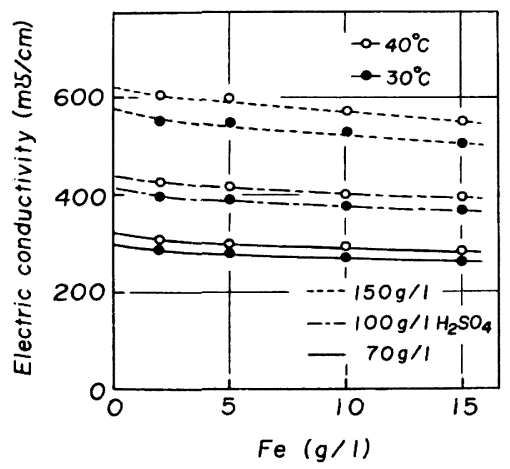

Fig. 4. Influence of concentration of $\mathrm{Fe}$ to electric conductivity in a pickling bath.

\section{3 電気亜鉛めつき浴}

ここでは，めつき浴が硫酸亜鉛，硫酸アンモニウム， および硫酸から構成される場合について検討する，この 処理浴では，pH の管理を蕨しく要求されるので，それ

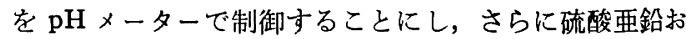
よび硫酸アンモニウムの検出端として電導度法と比重法 
の適用性について調べた.

まず，硫酸覀鉛および硫酸アンモニウムについて，濃 度と電導度との関係を調べた結果を Fig. 5〜6 に示す. すなわち，硫酸亜鉛が高濃度であつても電導度そのもの が小さいため検出感度が低くなつている，また，硫酸亜 鉛，硫酸アンモニウムともにその濃度変化がそれぞれ電 導度に影響を与えるので，それだけ電導度法は測定誤差 が大きくなる。

一方，硫酸亜鉛および硫酸アンモニウムを含む溶液に 硫酸を添加して pH を下げていくと，Fig. 7 に示すよう にある $\mathrm{pH}$ より小さいところで電導度が急上昇する傾向 が認められる、したがつて， pH の変化が大きいところ では電導度の変化量も大きいため, 電導度法によつて硫 酸亜鉛あるいは硫酸アンモニウムの濃度を管理すること

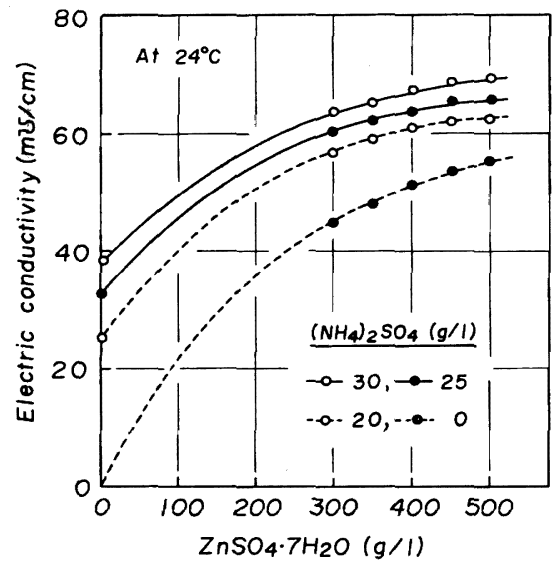

Fig. 5. Correlation between concentration of $\mathrm{ZnSO}_{4} \cdot 7 \mathrm{H}_{2} \mathrm{O}$ and electric conductivity in an electric galvanizing bath.

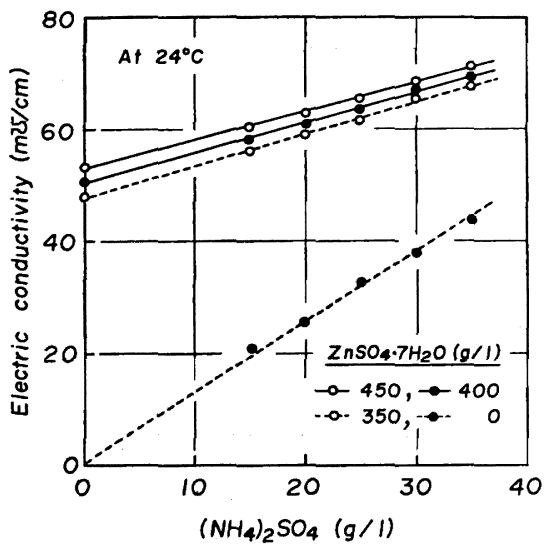

Fig. 6. Correlation between concentration of $\left(\mathrm{NH}_{4}\right)_{2} \mathrm{SO}_{4}$ and electric conductivity in an electric galvanizing bath.
は困難であるように思われる.

そこで，硫酸亜鉛と硫酸アンモニウムについて，それ ぞれの濃度と比重との関係を調べた。その結果を Fig. $8 \sim 9$ に示す. 例光ば, 硫酸亜鉛量が $350 〜 450 \mathrm{~g} / 1$ の 範囲で 変化する場合，その中の硫酸アンモニウム量が $25 \mathrm{~g} / 1$ で一定であるとすると，比重は 1.20 から 1.25 まで変化する．また，硫酸アンモニウム量が $\pm 5 \mathrm{~g} / \mathrm{l}$ だ け変化すると, 比重は \pm 0.0025 変化し, これは硫酸覀 鉛量に換算すると $\pm 5 \mathrm{~g} / \mathrm{l}$ に相当する. したがつて，め つき浴中の成分のなかで, 硫酸亜鉛量が他の成分と比較 してきわめて多いときには, 浴の比重は主に硫酸垔鉛の 濃度によつてきまつてくる.

以上の検討結果から，めつき浴中の硫酸亜鉛濃度は， 0.01 のオーダーまで信頼できる比重計を用いることに

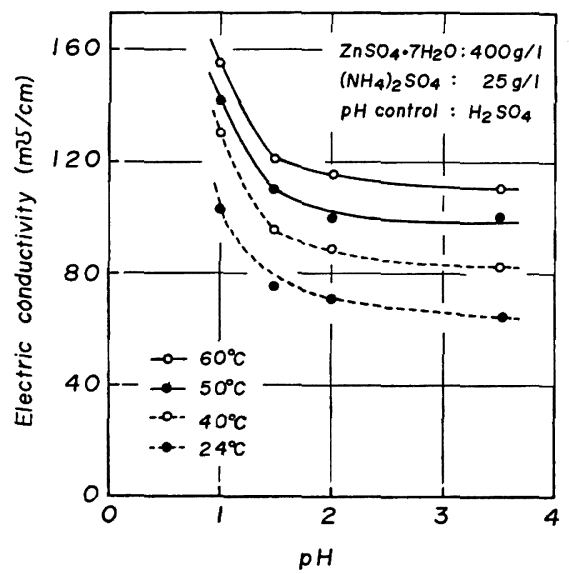

Fig. 7. Correlation between $\mathrm{pH}$ and electric conductivity in an electric galvanizing bath.

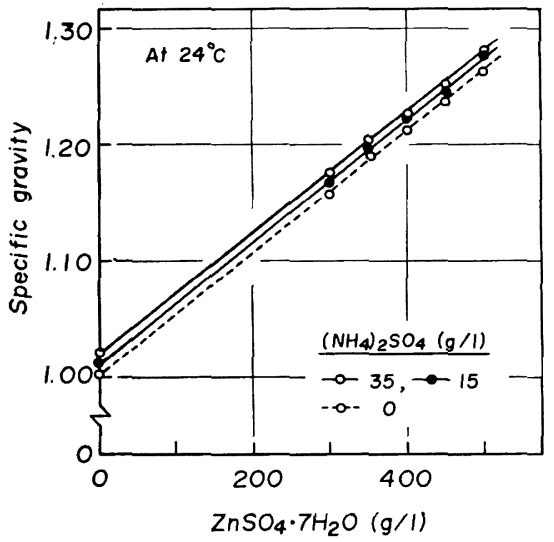

Fig. 8. Correlation between concentration of $\mathrm{ZnSO}_{4} \cdot 7 \mathrm{H}_{2} \mathrm{O}$ and specific gravity in an electric galvanizing bath. 


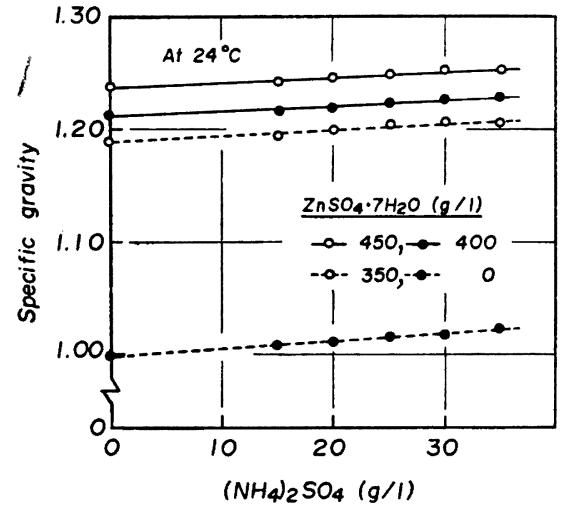

Fig. 9. Correlation between concentration of $\left(\mathrm{NH}_{4}\right)_{2} \mathrm{SO}_{4}$ and specific gravity in an electric galvanizing bath.

よつて自動管理が可能であるといえるなお，浴中に共 存する硫酸，鉄およびアルミニウムなどの量はわずかで あり，比重に与える影響は無視できる程度であると考え られる、また，浴温が例えば $40 \sim 60^{\circ} \mathrm{C}$ に変化したとき の比重の変化は 0.005 以下であつた.

\section{4 電解洗浄浴}

めつきおよびボンデ処理後の電解洗浄には炭酸アンモ ニウム溶液が使用される．炭酸アンモニウム溶液につい て濃度と電導度，との関係を調べた結果を Fig. 10 に, また濃度と $\mathrm{pH}$ との関係を調べた結果を Fig. 11 に示す. 炭酸アンモニウムの濃度は電導度との間に良好な相関関 係が得られているが， $\mathrm{pH}$ との相関は良好とはいえない。 したがつて, 電解洗浄浴中の炭酸アンモニウムの濃度は 電導度法によつて自動管理が可能である.

\section{5 電解クロメート処理浴}

電気亜鉛めつきされた銅板は電解洗浄処理した後,さ

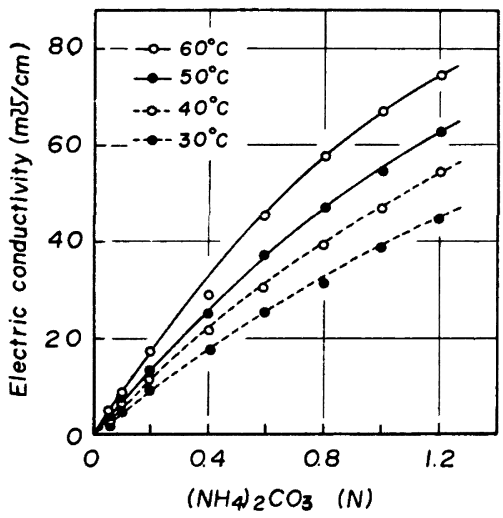

Fig. 10. Correlation between concentration of $\left(\mathrm{NH}_{4}\right)_{2} \mathrm{CO}_{3}$ and electric conductivity in an electrolytic cleaning bath.

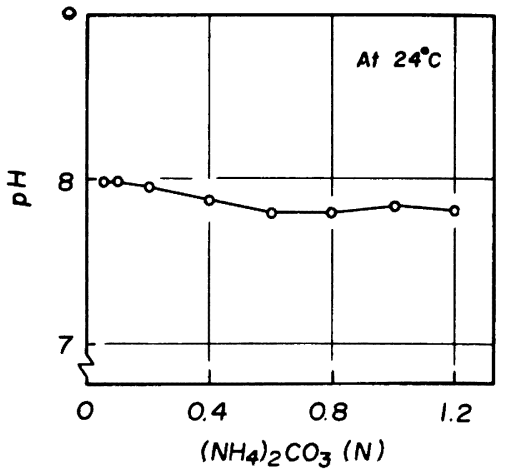

Fig. 11. Correlation between concentration of $\left(\mathrm{NH}_{4}\right)_{2} \mathrm{CO}_{3}$ and $\mathrm{pH}$ in an electrolytic cleaning bath.

らに無水クロム酸とナトリウム系添加物を含む処理浴で 電解クロメート処理される. この無水クロム酸とナトリ ウム系添加物について濃度と電導度, 濃度と比重のそれ ぞれの関係を調べた結果を Fig. 12〜13 に示す. すなわ ち, この処理浴の電導度は主としてクロム酸の濃度によ つてきまり，比重は両成分が同じ程度にきいてくる．し たがつて, 電導度法によつてクロム酸量を測定し, 比重 法によつてクロム酸とナトリウム系添加物の総量を測定 することによつて，それぞれの成分濃度を知ることがで きる.

例えば，ナトリウム系添加物の濃度が $20 \mathrm{~g} / 1$ の溶液を 基準とし, 電導度からクロム酸の量を求めると, ナトリ ウム系添加物の濃度が $\pm 5 \mathrm{~g} / 1$ 変動したときの誤差はク 口ム酸の量に換算して $\pm 1.5 \mathrm{~g} / 1$ に相当する. また，比

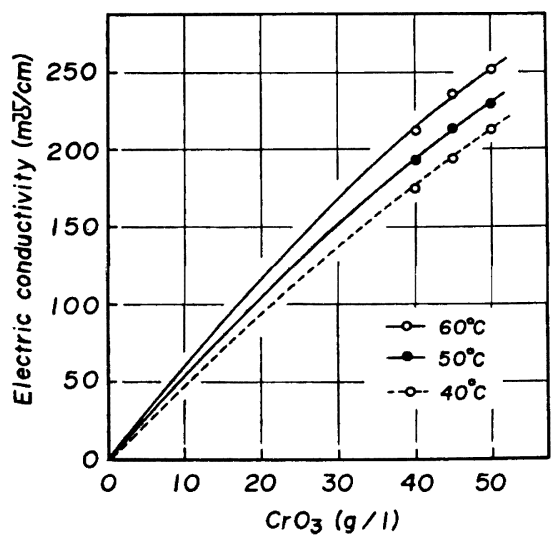

Fig. 12. Correlation between concentration of $\mathrm{CrO}_{3}$ and electric conductivity in an electrolytic chromate bath, in the case of $20 \mathrm{~g} / 1$ of addition. 


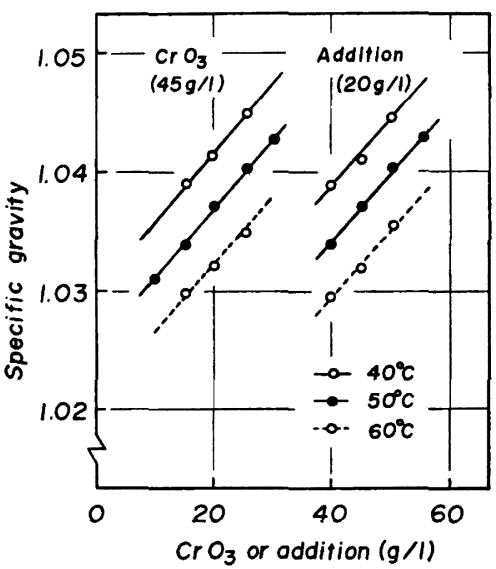

Fig. 13. Correlation between concentration of $\mathrm{CrO}$, or its addition and specific gravity in an electrolytic chromate bath.

重から両成分濃度の和を求めると，かりにクロム酸が $45 \pm 5 \mathrm{~g} / \mathrm{l}$, ナトリウム系添加物が $20 \pm 5 \mathrm{~g} / 1$ の範囲内で 変化した場合の測定誤差は $\pm 1.5 \mathrm{~g} / \mathrm{l}$ である.なお，比 重に対する温度の影響を調べたところ，例えば，クロム 酸 $45 \mathrm{~g} / \mathrm{l}$ ，ナトリウム系添加物 $20 \mathrm{~g} / 1$ の溶液の場合で, 室温付近での $1^{\circ} \mathrm{G}$ あたりの比重変量は 0.0005 程度で あつた。

以上の検討結果をもとにして，電解クロメート処理浴 の浱度を電導度計と比重計によつて自動管理するシステ ムについてさらに検討を加えた. 多くのシステムが考え られるがその一例を Fig. 14 に示す.このシステムは電 導度および比重の検出端，指示電送計，記録計，液面計

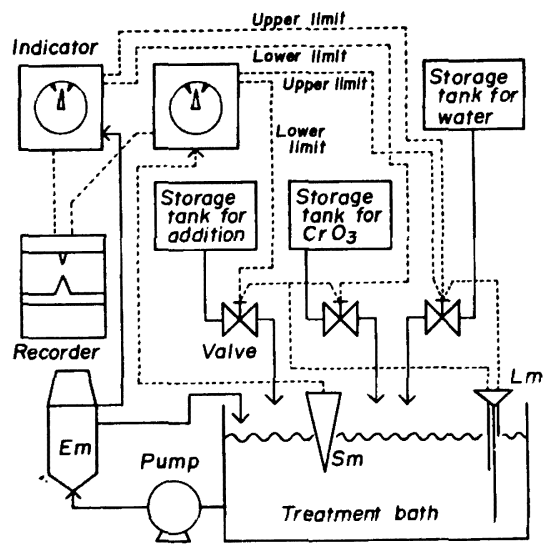

Fig. 14. An automatic control system for concentration of components in an electrolytic chromate bath. Em indicates electric conductivity cell, Sm specific gravity meter, and Lm liquid-level meter.
などから構成される，電導度指示計にはク口ム酸濃度の 管理目標の上限，下限接点を設け，上限接点によつて純 水タンクの電磁弁を，下限接点によつてクロム酸溶液夕 ンクの電磁弁を開閉してクロム酸の濃度を調節する．比 重指示計にはクロム酸とナトリウム系添加物濃度の和の 管理目標を設定し，上限を越えた場合は純水を加え，下 限よりも低下した場合はナトリウム系添加物溶液タンク の電磁弁を開いて液を送り濃度を調節する. したがつ て, どちらの一成分の濃度が高くなつても水が加えら れ，そのために他の成分の濃度が下限よりも低下すると その成分も補給されることになる. 制御方式はオンーオ フ制御であるが, 液面計からの信号を優先させることに よつて，処理浴槽の液面が上限に達するといずれの電磁 弁も開かず，また液面が下限よりも下がると両方の溶液 タンクの電磁弁が開いて液面が上限に達するまで両方の 成分液を注入補給されるようにすることができる。

\section{4. 実工程への適用結果}

以上に述べたように, $\mathrm{pH}$ 計, 電導度計, 比重計など を組み合わせることによつて電気亜鉛めつき工程中のめ つき浴およびその他の種々の化学処理浴の濃度を連続的 に自動分析できることを確認した。

ここで, 実工程における本方式の適用性を確かめるた めに，まず，電気亜鉛めつき浴の硫酸亜鉛の濃度管理に 適用した場合について，化学分析值との対応性を調べ た. その結果を Fig. 15 に示す. すなわち, 両者の值は よく一致しており，十分実用性があることが認められ る.

また，Fig. 14 に示した電解クロメート処理浴の自動濃

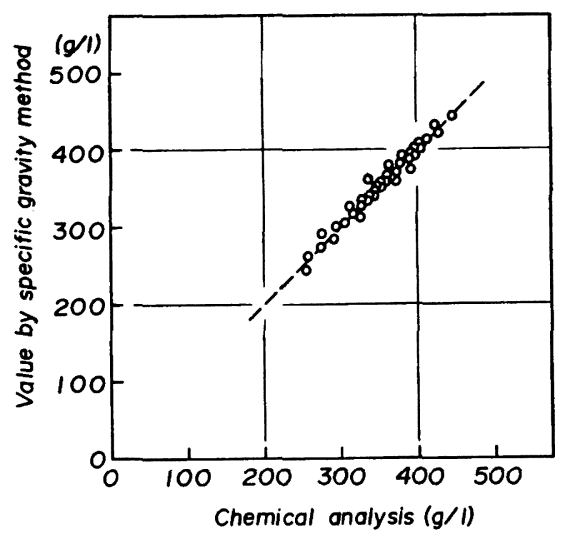

Fig. 15. Comparison between concentration of $\mathrm{ZnSO}_{4} \cdot 7 \mathrm{H}_{2} \mathrm{O}$ in an electric galvainzing bath by chemical analysis and that by specific gravity method. 


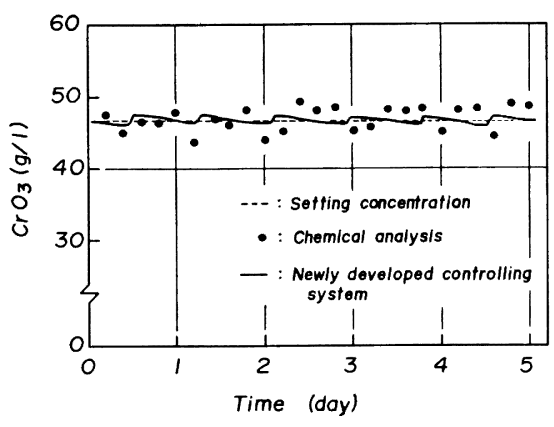

Fig. 16. Comparison between change of concentration of $\mathrm{CrO}_{3}$ in an electrolytic chromate bath by chemical analysis and that by newly developed controlling system.

度管理システムの適用性を, 従来からの化学分析法によ る間けつ的な制御方式と対比して調べた. その結果は, Fig. 16 に示すとおりであり，本方式のほうがばらつきも 少なく安定した操業のできることが明らかである.

\section{5. 結言}

電気覀鉛めつき工程におけるめつき浴をはじめとする
5 種の化学処理浴について, 自動濃度管理システムの基 礎的検討を行い，つぎのような諸点を明らかにした。

（1）アルカリ洗浄および電解酸洗浴中のアルカリと 酸の濃度は，電導度計で管理することができる.

（2）電気亜鉛めつき浴中の硫酸覀鉛の濃度は比重計 によつて検出し, 硫酸の濃度を $\mathrm{pH}$ 計の信号で調整する ことによつて，自動管理が可能である.

(3) 電解洗浄浴中の炭酸アンモニウムの濃度は電導 度計で, また電解クロメート処理浴中のクロム酸とナト リウム系添加物の濃度は電導度計と比重計の併用によつ て自動的制御することができる.

\section{交献}

1) 松本龍太郎, 鉄と鋼, 60 (1974)，13，p. 1843

2 ) 松本龍太郎：特殊鋼，26 (1977), 8, p. 20

3 ) 松本龍太郎, 佐藤公隆, 鈴木堅市, 川瀬平久：鉄 と鋼，65(1979), p. 1614

4 ) 工業計測技術大系編集委員会編：工業分析 (下), 工業計測技術大系 7，(1969)，p. 38 [日刊工業 新聞社] 